\title{
Cervical mucus sialic acid content determines the ability of frozen-thawed ram sperm to migrate through the cervix
}

\author{
L Richardson 1,2, J P Hanrahan², T Tharmalingam³, S D Carrington³, P Lonergan¹, A C O Evans ${ }^{1}$ \\ and S Fair ${ }^{4}$ \\ ${ }^{1}$ School of Agriculture and Food Science, University College Dublin, Belfield, Dublin 4, Ireland, ${ }^{2}$ Teagasc, Animal \\ Production Research Centre, Athenry, Co. Galway, Ireland, ${ }^{3}$ School of Veterinary Medicine, University College \\ Dublin, Belfield, Dublin 4, Ireland and ${ }^{4}$ Department of Biological Sciences, Laboratory of Animal Reproduction, \\ Faculty of Science and Engineering, University of Limerick, Limerick, Ireland
}

Correspondence should be addressed to S Fair; Email: sean.fair@ul.ie

\begin{abstract}
The aim of this study was to investigate the properties and to functionally characterize the cervical mucus that modulates sperm transport through the cervix by using ewe breeds with a divergent pregnancy rate (Belclare and Suffolk; high and low, respectively) following cervical insemination using frozen-thawed semen. Sperm number, as well as sialic acid and fucose content in both the channels and in the lumen of different regions of the cervix were quantified in inseminated Belclare and Suffolk ewes. Expression of glycosyltransferase and MUC genes, glycosidase activity and sialic acid speciation in follicular phase cervical tissue and mucus were assessed. More spermatozoa were found in the cervical channels in the region closest to the cervical os in Belclare than Suffolk ewes $(P<0.05)$ and Suffolk ewes had a higher sialic acid content in the cervical channels than Belclare ewes $(P<0.05)$ in all regions of cervix. Suffolk ewes had significantly higher expression of FUT1, ST6GAL1 and MUC5AC than Belclare ewes. There was no difference between the breeds in glycosidase activity $(P>0.05)$. Levels of Neu5Ac were higher in Belclare than Suffolk ewes $(P<0.05)$ and levels of Neu5Gc was higher in Suffolk than Belclare ewes $(P<0.05)$. Competitive sperm penetration assays demonstrated that frozenthawed sperm progression increased when cervical mucus was incubated with sialyllactose prior to a sperm penetration test $(P<0.05)$. These results suggest that the difference between Belclare and Suffolk ewes in sperm transport with frozen-thawed semen is due to the higher concentration of sialic acid within channels, which binds to spermatozoa and reduces their ability to traverse the cervix.

Reproduction (2019) 157 259-271
\end{abstract}

\section{Introduction}

In many mammalian species, including humans and many livestock species including sheep and cattle, semen is deposited against the external cervix os in the anterior vagina at mating. Spermatozoa then encounter a significant number of obstacles in their passage to the site of fertilization, the first of which is the cervix itself. Due to the variable biophysical characteristics of cervical mucus, the cervix serves to prevent penetration of pathogens and only allows passage of spermatozoa into the uterus during the periovulatory period (Katz et al. 1997, Kolle 2015).

The cervix has a complex three-dimensional structure with location-specific secretory properties (Mullins \& Saacke 1989, Menarguez et al. 2003). In an extensive study of cattle, the cervical mucosa was found to consist of longitudinally arranged folds and grooves, which originated within the vagina fornix (Mullins \& Saacke 1989). These grooves were described as forming channels which traverse the cervical os, continue through each annular cervical ring, leading to the uterus, forming the so-called privileged pathways for sperm transit to the uterus (Mullins \& Saacke 1989). Similar folds have also been described in women (Kessel 1979) but not in other species. These observations indicate that the cervix supports the passage of normal spermatozoa through cervical channels by a combination of orientating against a flow (rheotaxis; Miki \& Clapham 2013) as well as surface tracking behaviour (thigmotaxis) while abnormal spermatozoa found in the lumen may be subject to removal by retrograde mucus flow (Sakkas et al. 2015).

Histochemical studies of the cervix of cows, goats and sheep have revealed that the composition of mucus found deep in the channels is different than those found in the lumen during the ovulatory phase (Mullins \& Saacke 1989, Pluta et al. 2011). Cervical mucus is a viscoelastic secretion produced constantly by secretory epithelial cells of the cervix. Changes in the biochemical and physical properties of cervical mucus during different 
phases of the menstrual (Martyn et al. 2014) and oestrous cycles (Pluta et al. 2012) are known to correlate with the ability of spermatozoa to travel through the cervix (Morales et al. 1993, Tung et al. 2017). Cervical mucus is composed mostly of water with a complex mixture of organic components, inorganic ions, enzymes, bacterial proteins and mucins (Bansil \& Turner 2006, Curlin \& Bursac 2013, Fernandez-Hermida et al. 2018). Mucins are high-molecular-weight glycoproteins that consist of hundreds of oligosaccharide chains linked to a protein backbone. They form the molecular scaffolding of mucus gels (Cone 2009) and changes in the glycosylation pattern of mucins are reflected in changes in the physiochemical properties during the cycle (AnderschBjorkman et al. 2007). The terminal positions of the cervical mucus oligosaccharide chains are commonly occupied by either fucose or sialic acid and in human cervical mucus, terminal sialic acid dominates before and after ovulation, while around ovulation fucose in the terminal position is more prevalent (AnderschBjorkman et al. 2007).

In sheep, cervical artificial insemination (AI) with frozen-thawed semen is not widely used internationally due to unacceptably low pregnancy rates (typically $<30 \%$ ) which have been attributed to the inability of the sperm to penetrate the ovine cervix (Kaabi et al. 2006). The exception is in Norway where farmers perform cervical as well as vaginal (so-called shot-in-the-dark) insemination and achieve acceptable pregnancy rates (in excess of $60 \%$; Paulenz et al. 2005, 2007). We have previously shown that this is likely due to the ewe breed used in Norway, as pregnancy rates in sheep following cervical Al with frozen-thawed semen are dependent on ewe breed (Donovan et al. 2004). In particular, irrespective of sire breed, cervical insemination with frozen-thawed semen in Belclare and Suffolk ewes results in dramatically divergent pregnancy rates (approximately 45 vs $15 \%$, respectively; Donovan et al. 2004). This difference between ewe breeds is negated when laparoscopic insemination is performed (Fair et al. 2005), pointing to inherent differences in sperm transport across the cervix. Here, we hypothesized that the difference in pregnancy rate between Belclare and Suffolk ewes after cervical Al is due to differences in the physicochemical properties of their respective cervical mucus. Specifically, the objective of this study was to investigate the properties and to functionally test the characteristics of cervical mucus that modulates sperm transport through the cervix.

\section{Materials and methods}

\section{Experimental design}

All procedures involving animals were in accordance with the European Union Directive 2010/36/EU and University College Dublin's animal research ethics committee approved the study. Three experiments were performed to investigate the properties and functional characteristics of cervical mucus. Multiparous Belclare and Suffolk ewes were used in Experiments 1 and 2, as a pregnancy rate of $44 \%$ is typically achieved with Belclare ewes following cervical insemination using frozen-thawed semen, while for Suffolk ewes pregnancy rate rarely exceeds 18\% (Donovan et al. 2000, Donovan et al. 2004, Fair et al. 2005). In Experiment 3, multiparous ewes of various breeds were used. The frozen-thawed semen used in this study was processed and frozen according to previously reported procedures (Donovan et al. 2004).

\section{Experiment 1}

\section{Animals and sample collection}

The objectives of this experiment were to (i) characterize the number and location of spermatozoa within the cervix and (ii) quantify sialic acid and fucose within the cervical lumen and channels in Suffolk and Belclare ewes. Oestrus was synchronized in 18 Belclare and 14 Suffolk multiparous ewes with a progestagen-impregnated vaginal pessary containing $20 \mathrm{mg}$ fluorogestone acetate (Chronogest, Intervet, Boxmeer, The Netherlands). The pessaries were removed after 12 days and the ewes were administered 500 IU eCG (Intervet, Boxmeer, The Netherlands) intramuscularly. Ewes were inseminated using semen from a single Suffolk ram of proven fertility at $57 \mathrm{~h}$ post pessary removal. Straws containing $200 \times 10^{6}$ spermatozoa were thawed at $70^{\circ} \mathrm{C}$ for $8 \mathrm{~s}$ immediately prior to insemination. The cervix was located, via a speculum with a light source, and insemination was performed by depositing the semen as far as possible into the cervix, without using force, by means of an insemination pipette with a bent tip (Minitüb GMBH, Tiefenbach, Germany; Fair et al. 2005). There was no difference in depth of penetration between the breeds (data not shown). All ewes were slaughtered in a commercial abattoir $4 \mathrm{~h}$ after $\mathrm{Al}$ and the reproductive tracts were immediately recovered. Each cervix was isolated and its length was recorded. Each cervix was then cut transversely into eight regions of equal length, using a microtome blade. Four regions (Fig. 1), comprising of alternate regions from just after the cervical os (hereafter named Region 1) to just before the uterus (hereafter named Region 4), were fixed in $4 \%$ paraformaldehyde for $24 \mathrm{~h}$. The remaining four regions were discarded. Both utero tubule junctions (UTJs) from each ewe were removed and were also fixed. All samples were then processed by dehydration through a series of ascending concentrations of alcohol, cleared in xylene and finally impregnated with paraffin wax.

\section{Determination of location and number of spermatozoa in the cervix}

Sections from each of the four retained regions were cut at a thickness of $7 \mu \mathrm{m}$ and every fifth section was mounted on uncoated slides and dried overnight at $37^{\circ} \mathrm{C}$. Sections were stained using a haematoxylin and eosin, observed under $400 \times$ magnification and the number of spermatozoa heads on each slide was counted. This was performed on four slides per region, resulting in 16 counts per animal over the length of the 


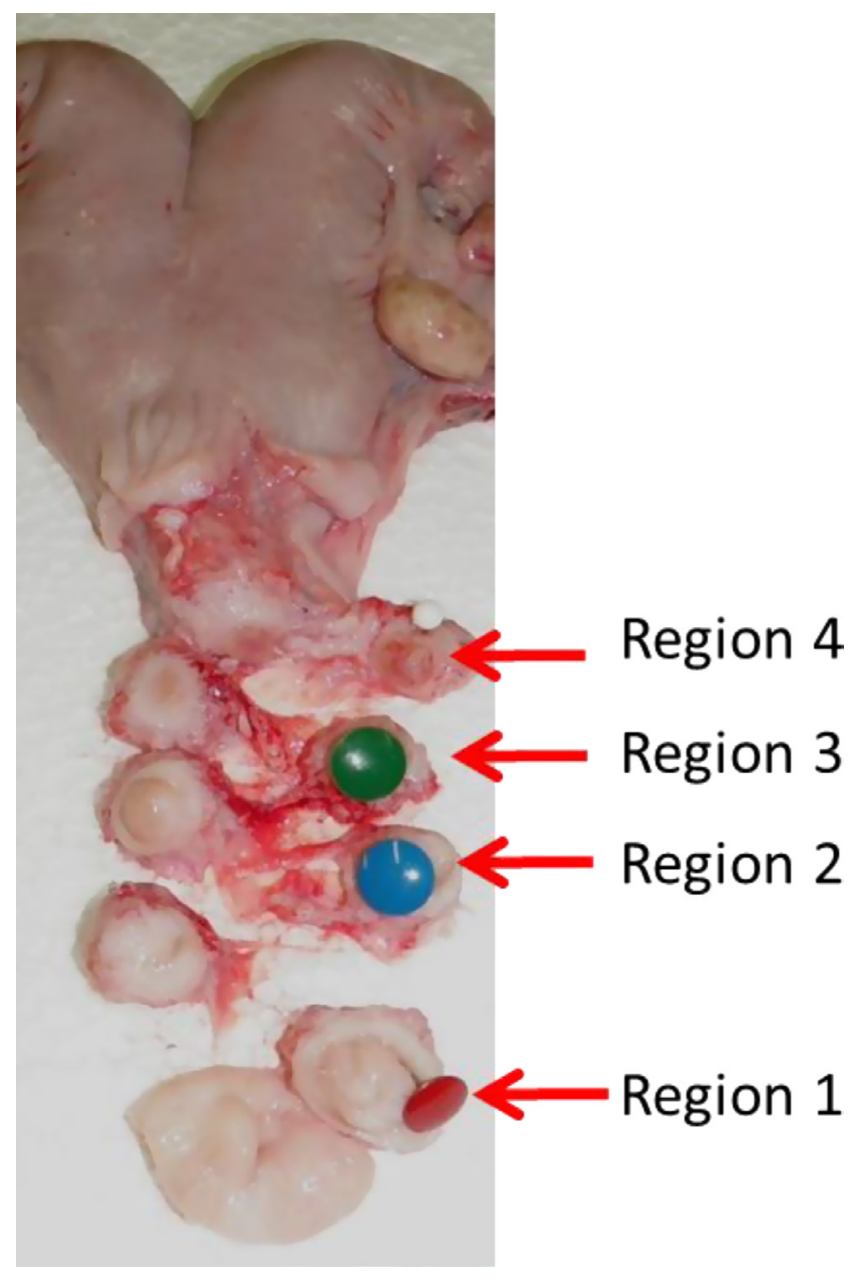

Figure 1 Isolated cervical regions, comprising of regions from just after the cervical os (Region 1) to just before the uterus (Region 4).

cervix. This was repeated for each UTJ for each ewe, with four sections cut and examined per UTJ.

\section{Sialic acid and fucose quantification}

Sambucus nigra lectin (Vector Labs, Peterborough, UK), specific for sialic acid (NeuAc/NeuGc $\alpha 2,6 \mathrm{Gal}-\mathrm{GalNac}$ ), and Ulex europaeus lectin (Vector Labs), specific for fucose ( $\alpha$-L-Fuc), were used at concentrations of 1 and $15 \mu \mathrm{g} / \mathrm{mL}$, respectively. Slides with cervical tissue were deparaffinized by two washes in xylene and rehydrated through a series of graded alcohol steps (100 and $70 \%)$ and incubated in methanol containing $0.3 \% \mathrm{H}_{2} \mathrm{O}_{2}$ for $10 \mathrm{~min}$ to block the activity of endogenous peroxidase. Thereafter, every step was followed by washing with phosphate buffered saline (PBS; Sigma) at $\mathrm{pH}$ 7.5. Slides were incubated with biotin-conjugated lectins, Sambucus nigra or Ulex europaeus, for $1 \mathrm{~h}$ at room temperature. Avidinbiotin complex (Vectastain Elite ABC Kit, Vector Labs) was then added to the slides and they were incubated for $20 \mathrm{~min}$ following which, 3,3'-diaminobenzidine tetrahydrochloride chromogen substrate was added to the slides which were then incubated for $5 \mathrm{~min}$. The slides were then washed under running tap water for $7 \mathrm{~min}$. This was followed by dehydration using increasing concentrations of alcohol (70 and 100\%) for 5 min each and subsequent clearing in two successive changes of xylene for $10 \mathrm{~min}$ each. Slides were mounted using DPX (AGB Scientific Ltd, Dublin, Ireland) and observed under $10 \times$ magnification. Using a digital camera, six images were captured per cervical region (three images showing cervical grooves and three images of cervical lumen). To quantify the amount of stained material, the area of the epithelium was measured and the proportion of the stained area was determined using colour segregation (Image-Pro Plus software, version 6.2, MediaCybernetics, Bethesda, MD, USA). Digital zoom was used to more accurately visualize and select the epithelial area. This was performed in each cervical region, resulting in 24 measurements per lectin for the cervix of each ewe. To confirm lectin specificity, controls with eluting sugars were performed. Sambucus nigra was incubated with lactose and Ulex europaeus was incubated with fucose for $30 \mathrm{~min}$ at room temperature prior to incubation with the tissues (Kiernan 2008). A negative control of the technique was performed in samples processed without lectin.

\section{Experiment 2}

\section{Animals and sample collection}

The aim of this experiment was to investigate the effect of ewe breed on the composition of cervical mucus and the gene expression of cervical tissues collected at oestrus. Oestrus was synchronized in multiparous Belclare and Suffolk ewes as described above. In Year 1, ewes were slaughtered in a commercial abattoir at either 42 (Belclare $n=7$; Suffolk $n=6$ ) or 57 (Belclare $n=8$; Suffolk $n=4$ ) h post pessary removal. These time points were chosen to represent the times when ewes are expected to be in oestrus ( $42 \mathrm{~h}$ ) and the periovulatory period $(57 \mathrm{~h})$. The reproductive tracts were recovered and the cervix was cut open longitudinally and a segment of mucosa from the mid-cervical region was dissected and placed in RNAlater (Ambion, Austin, TX, USA) for $24 \mathrm{~h}$. Following this it was stored at $-80^{\circ} \mathrm{C}$ until RNA extraction.

In Year 2, ewes were slaughtered at either 42 (Belclare $n=6$; Suffolk $n=4$ ), 48 (Belclare $n=8$; Suffolk $n=8$ ) or 57 (Belclare $n=5$; Suffolk $n=5$ ) $\mathrm{h}$ post pessary removal. The cervix was cut open longitudinally and a segment from the mid-cervical region was preserved for RNA extraction as described above.

To examine glycosidase activity, swabs of the cervical mucosa were taken (two swabs per animal) and placed immediately into $2 \mathrm{~mL}$ of PBS. This was centrifuged at $5000 \mathrm{~g}$ at $4^{\circ} \mathrm{C}$ for $5 \mathrm{~min}$ and the supernatant was stored at $-20^{\circ} \mathrm{C}$ for glycosidase activity assays. To determine the quantity of the most frequently found forms of sialic acid, guanidine hydrochloride ( $8 \mathrm{M} \mathrm{GdnCl}$, Sigma) was pipetted onto the cervical tissue and placed on a horizontal shaker for $5 \mathrm{~min}$. The mucus-GdnCl mixture was then collected using a hand suction pump (Res-Q-Vac) and mixed overnight at room temperature to obtain a homogeneous mixture. This was then stored at $4^{\circ} \mathrm{C}$ until purification. 


\section{RNA extraction and CDNA synthesis}

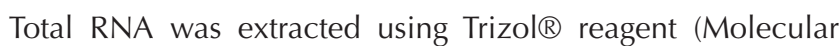
Research Center Inc. Cl, USA) according to the manufacturer's instructions. Briefly, the segment of the cervical mucosa stored at $-80^{\circ} \mathrm{C}$ was cut into small pieces and transferred into a sterile $2 \mathrm{~mL}$ eppendorf containing $1 \mathrm{~mL}$ of Tri Reagent and a $5 \mathrm{~mm}$ stainless steel bead (Qiagen, Crawley, West Sussex, UK). The tissue was then homogenized using Tissuelyser (Qiagen) at $30 \mathrm{~Hz}$ (1800 oscillations/min) for $6 \mathrm{~min}$ and incubated at room temperature for $5 \mathrm{~min}$. Following homogenization, bromo-3-chloro-2-propanol (BCP) and isopropanol (Sigma) steps were performed and the RNA was resuspended in $100 \mathrm{~mL}$ RNase- and DNase-free water. RNA clean-up and on-column DNase digestion were performed using the Qiagen RNeasy mini kit (Qiagen) according to the supplier's recommendations. Total RNA concentration was quantified using nanodrop spectrometry at $260 \mathrm{~nm}$ (Beckman Coulter Ltd, Co Clare, Ireland). RNA quantity and quality was assessed using both a NanoDrop (Thermo Scientific, Dublin, Ireland) and an Agilent 2100 Bioanalyzer (Agilent Technologies, Santa Clara, CA, USA), with all samples having a 260/280 ratio greater than 1.8 and RIN greater than 8.0. Complementary DNA was synthesized from $5 \mu \mathrm{g}$ of total RNA using the High Capacity cDNA reverse transcriptase kit (Applied Biosystems, Foster City, CA). Absence of contamination with genomic DNA was confirmed by preparation of samples without reverse transcriptase (minus-RT controls).

\section{Quantitative real-time PCR}

The expression of the glycosyltransferases, ST6GAL1 and FUT1, which transfer either sialic acid or fucose in an $\alpha 2,6$ linkage to an underlying galactose residue, and MUC-5AC, $-5 B$ and -6 , which encode gel-forming secreted mucins, was determined. Oligonucleotide primers for real-time QRT-PCR were designed using Primer3 version 4.0 (http://frodo.wi.mit.edu/primer3) and commercially synthesized (MWG Biotech, Germany). A BLAST search of the ovine expressed sequence tag (EST) database at the NCBI GenBank using bovine gene sequences was performed on genes not sequenced in the sheep at the time of design. PCR primers were designed on EST clones that showed a high degree of homology with the bovine sequences (Supplementary Table 1, see section on supplementary data given at the end of this article). Non-template controls, minus-RT controls and a 6-point, 2-fold dilution series were included and PCR efficiencies were determined using the serial dilutions. The qPCR assays were performed using a 7500 instrument (Applied Biosystems) in a $20.0 \mu \mathrm{L}$ reaction volume, containing 1X Power SYBR $®$ Green Master mix (Applied Biosystems), $5.0 \mu \mathrm{L}$ cDNA (2.5 ng of total RNA equivalents) and $300 \mathrm{nM}$ final concentration each of forward and reverse primer. The PCR thermal cycling programme consisted of one cycle at $50^{\circ} \mathrm{C}$ for $2 \mathrm{~min}$, one cycle at $95^{\circ} \mathrm{C}$ for $10 \mathrm{~min}$, followed by 40 cycles at $95^{\circ} \mathrm{C}$ for $15 \mathrm{~s}$ and $60^{\circ} \mathrm{C}$ for $1 \mathrm{~min}$. All data were analysed using the qBAse software package, using efficiency correction and normalization, which was performed using the two reference genes RPL19 and RPLP0. These had been identified as optimal using the geNorm algorithm (geNorm $M>0.15$ : Vandesompele, 2002) out of a panel of four genes tested (ATPASE, ACTB, RPLPO, RPL19).

\section{Glycosidase activity}

Glycosidase activity in cervical mucus samples was assayed using a fluorescent glycosidase assay based on that of Irwin et al. (2004). Total protein concentration in mucus samples was quantified in order to standardize enzyme levels using the Fluoroprofile Protein Quantification Kit according to manufacturer's instructions (Sigma). All assays were carried out in triplicate. The activity of sialidase was read using a spectrophotometeric plate reader (Asys Hitech UVM 340 Microreader) at $405 \mathrm{~nm}$. A molar extinction coefficient for $p$-nitrophenol of $\varepsilon=17,700 \mathrm{M}^{-1} \mathrm{~cm}^{-1}$ was used to calculate sialidase activity (Kremp \& Anderson 2004). Fucosidase, galactosidase and hexosaminidase activities were read in a fluorescent plate reader (SpectraMax Gemini, Molecular Devices, CA, USA), at an excitation wavelength of $365 \mathrm{~nm}$ and emission of $460 \mathrm{~nm}$. The concentration was calculated by reference to a standard curve $(0$ to $80 \mu \mathrm{M})$ of 4-methylumbelliferone (Corfield \& Myerscough 2000).

\section{Sialic acid speciation}

Mucins were purified from cervical mucus samples using previously described methods (Ellingham et al. 1999, Royle et al. 2008). Briefly, cervical mucus, stored in guanidine hydrochloride, was first purified using gel filtration chromatography in order to extract the cervical mucins for sialic acid analysis. The density of the samples were adjusted to $1.40 \mathrm{~g} / \mathrm{mL}$ with $\mathrm{CsCl}$ and centrifuged for $18 \mathrm{~h}$ at $65,000 \mathrm{rpm}$ at $10^{\circ} \mathrm{C}$. The density gradient thus formed was unpacked and the mucin-rich fractions ( 1.35 to $1.45 \mathrm{~g} / \mathrm{mL}$ ) were used in the next step. Samples were run on Sepharose CL-2B column $(1 \times 50 \mathrm{~cm})$ with $50 \mathrm{mM}$ Tris $100 \mathrm{mM} \mathrm{KCl}, \mathrm{pH} 7.5$, buffer. Fractions were collected using a fraction collector and mucin content was monitored by slot blotting according to techniques described previously (Thornton et al. 1989). Samples that contained mucins were run on a Sephadex G25 column $(2.5 \times 90 \mathrm{~cm})$. Fractions were collected and mucin content was detected as in the previous step. Collected fractions containing mucins were freeze dried and stored at $-20^{\circ} \mathrm{C}$.

To analyse sialic acid speciation, sialic acids from purified mucins were differentiated by removal from the mucin glycan, followed by fluorochrome labelling. Sialic acids were released from the dried mucin samples $(25 \mu \mathrm{g})$ using mild acid hydrolysis by incubation for $2 \mathrm{~h}$ at $80^{\circ} \mathrm{C}$ with $100 \mu \mathrm{L}$ of $2 \mathrm{M}$ acetic acid in a thermostatically controlled water bath. Samples were then dried using a Rotary SpeedVac and resuspended in $5 \mu \mathrm{L}$ MilliQ water. The labelling of sialic acids was undertaken using a LudgerTag DMB (1,2-diamino-4,5-methylenedioxybenzene) Sialic Acid Labelling Kit (Ludger Limited, Culham Science Centre, Abingdon, UK). DMB (0.7 mg) was added to sodium dithionite $(0.4 \mathrm{mg})$ in mercaptoethanol $(1.2 \mathrm{M})$ and $20 \mu \mathrm{L}$ was added to the sialic acids for $3 \mathrm{~h}$ at $50^{\circ} \mathrm{C}$. The reaction was quenched by the addition of $475 \mu \mathrm{L}$ of MilliQ water 
and samples were immediately frozen at $-20^{\circ} \mathrm{C}$. Analysis was subsequently carried out using high performance liquid chromatography (HPLC).

For the purpose of identification and quantification, individual ( $\mathrm{N}$-glycolyl and $\mathrm{N}$-acetyl) and mixed sialic acid standards obtained with the Ludger kit were also labelled as described above. Analysis was done promptly after labelling to avoid DMB degradation (which occurs over time). Analytical separation of the labelled samples was undertaken by HPLC using a Waters Alliance 2695 Separations Module with a Waters 2475 Multi Wavelength Fluorescence Detector (Waters Corporation, Millford, MA, USA). Waters Empower Chromatography Workstation software (build 1154) was used for system control and data processing. The analytical column used was a Waters XBridge $C_{18} 2.1 \times 150 \mathrm{~mm}, 3.5 \mu \mathrm{m}$ BEH silica column (Waters Corporation). Gradient separations were performed using a mobile phase of $10 \mathrm{mM}$ ammonium formate, at $\mathrm{pH} 4.4$ and acetonitrile as solvent $\mathrm{A}$ and solvent $\mathrm{B}$, respectively. Details of the gradient were: solvent $B$ increased linearly from 0 to $50 \%$ in $40 \mathrm{~min}$, followed by a sharp linear increase to $100 \%$ in $0.1 \mathrm{~min}$, with a subsequent isocratic hold for a further $5 \mathrm{~min}$ to remove adsorbed hydrophobic sample components. Initial conditions were restored in $0.1 \mathrm{~min}$ followed by a $15 \mathrm{~min}$ re-equilibration time. The flow rate was $200 \mu \mathrm{L} / \mathrm{min}$. The separation temperature was set at $25^{\circ} \mathrm{C}$ while the sample temperature was $5^{\circ} \mathrm{C}$. An injection volume of $25 \mu \mathrm{L}$ was used for both samples and standards. Excitation and emission wavelengths for fluorescence detection were $\lambda=373 \mathrm{~nm}$ and $\lambda=448 \mathrm{~nm}$, respectively. The sialic acid speciation was determined by comparing the retention time of peaks isolated in samples to those from a sialic acid reference panel as provided by the Ludger kit. The integration of areas under the peaks gave relative levels of the sialic acid species.

Cervical mucus was initially purified and analysed from one ewe per breed at $42 \mathrm{~h}$ and two ewes per breed at $57 \mathrm{~h}$ post pessary removal. Following the initial results, the remaining samples were then pooled according to breed and time post pessary removal for analysis. Samples were pooled due to the time-consuming process of mucin purification. This resulted in four samples at $42 \mathrm{~h}$ post pessary removal (one individual ewe sample per breed and one pooled sample per breed) and six samples at $57 \mathrm{~h}$ post pessary removal (two individual ewe samples per breed and one pooled sample per breed) being analysed. As time post pessary removal had no effect on sialic acid speciation (see 'Statistical analysis' section) the data from each time point were pooled.

\section{Experiment 3}

\section{Animals and sample collection}

The aim of this experiment was to examine the effect of sialic acid on sperm penetration through cervical mucus. This was done in two ways, either by adding sialyllactose to cervical mucus or by adding sialyllactose to spermatozoa, prior to an in vitro mucus penetration test. Oestrus was synchronized, as previously described, in multiparous ewes of various breeds $(n=22)$. Ewes were restrained in a standing position and the cervix was located using an intravaginal speculum fitted with a light source. Mucus was aspirated from inside the cervical os using a flexible catheter (Aspiglaire, IMV, L'Aigle, France) at $57 \mathrm{~h}$ post pessary removal. Mucus from all ewes was pooled, mixed and divided into four equal aliquots.

Each aliquot was incubated at $37^{\circ} \mathrm{C}$ with $6^{\prime}$-sialyllactose (Carbosynth, Berkshire, UK) to obtain a final concentration of either 0 (Control), 10, 30 or $90 \mathrm{mM}$ sialyllactose and mixed for $1 \mathrm{~h}$ by rotating gently at $4{ }^{\circ} \mathrm{C}$. Following this, mucus was aspirated into flat glass capillary tubes $(0.3 \times 3.0 \times 100 \mathrm{~mm}$; Composite Metal Services, West Yorkshire, UK), marked in $10 \mathrm{~mm}$ intervals from 10 to $70 \mathrm{~mm}$. Care was taken to avoid trapping air bubbles within the tube and the top of each tube was sealed with Cristaseal (Hawksley, Sussex, UK). Straws from pooled ram semen from various ram breeds with proven fertility were thawed in a water bath at $70^{\circ} \mathrm{C}$ for $8 \mathrm{~s}$. The thawed semen was diluted in Tyrode albumin lactate pyruvate (TALP) media containing a 1\% fluorescent stain (Hoechst 33342, Sigma) to yield a final sperm concentration of $10 \times 10^{6} / \mathrm{mL}$ and incubated for $5 \mathrm{~min}$ at $37^{\circ} \mathrm{C}$.

The ability of spermatozoa to penetrate the mucus was assessed by placing four capillary tubes (representing one tube from each treatment) vertically into a $1.5 \mathrm{~mL}$ tube containing $250 \mu \mathrm{L}$ of the stained semen solution for $10 \mathrm{~min}$ at $37^{\circ} \mathrm{C}$. This was replicated 4 times per round of mucus collection. In order to fix the spermatozoa at their location point, the tubes were then placed on a hot plate at $45^{\circ} \mathrm{C}$ for $30 \mathrm{~s}$ to kill, and therefore immobilize, the spermatozoa. To assess the degree of sperm penetration through the cervical mucus the number of sperm, one field of view wide, at each of the $10 \mathrm{~mm}$ interval was counted using a fluorescent microscope $(40 x$; Olympus $\mathrm{BX})$. Mucus collection and incubation with sialyllactose was replicated 10 times over a 2 month period, resulting in 40 capillary tube counts per treatment. To confirm specificity of sperm binding, a subset of mucus was also incubated with $30 \mathrm{mM}$ of lactose prior to a sperm penetration test and was replicated 8 times.

The second part of this experiment involved assessing the effect of the addition of $6^{\prime}$-sialyllactose to frozen-thawed ram spermatozoa on its subsequent penetration through cervical mucus. Mucus was collected as previously described from multiparous ewes $(n=11)$ and was pooled, mixed and loaded into flat capillary tubes as above. Frozen ram semen straws were thawed in a water bath at $70^{\circ} \mathrm{C}$ for $8 \mathrm{~s}$ and separated into four equal aliquots. Each aliquot was diluted to a final sperm concentration of $10 \times 10^{6} / \mathrm{mL}$ with TALP medium containing $1 \%$ fluorescent stain (Hoechst 33342, Sigma) and 6 '-sialyllactose was added to give a final concentration of either 0 (Control), 5, 10, or $20 \mathrm{mM}$ and incubated for $20 \mathrm{~min}$ at $37^{\circ} \mathrm{C}$. Four capillary tubes were placed vertically into a $1.5 \mathrm{~mL}$ tube containing $250 \mu \mathrm{L}$ of one of the semen solutions and a sperm penetration test was performed as described above.

\section{Statistical analysis}

Data on sperm number in the cervix and lectin binding (Experiment 1) were analysed using Proc MIXED (SAS, 2003). 
The model used for sperm number data included effects for ewe breed, cervical region and their interactions. Lectin binding data were analysed using a model with effects for ewe breed, cervix location (channels or lumen), cervical region and their interactions. A log transformation was applied to data prior to analyses to normalize the distribution of residuals. Cervical length post slaughter was analysed using Proc GLM of SAS. Quantitative real-time PCR and glycosidase activity data (Experiment 2) were analysed using Proc MIXED of SAS, with a log transformation applied to data prior to analyses. Effects included in the model were ewe breed, time post pessary removal and their interaction. Orthogonal polynomials were used to partition the effects of time and breed-by-time interaction into linear and quadratic components so that breed effects on the pattern of change over time post pessary removal could be evaluated. Data on sialic acid speciation were analysed using the least squares means procedures Proc GLM of SAS (2003). The initial model included effects for ewe breed and time post pessary removal; however, time post pessary removal was dropped from subsequent analyses as it did not approach statistical significance. Data from the mucus penetration tests (Experiment 3) were analysed using Proc MIXED (SAS, 2003). The number of spermatozoa counted per capillary tube at each $10 \mathrm{~mm}$ point (one field of view wide), following a log transformation to normalize the residuals, was analysed using a model with sialyllactose concentration, position (interval mark) and replicate as fixed effects and sialyllactose concentration by replicate as a random term. Where transformations were involved the means are presented after back-transformation along with associated $95 \%$ confidence intervals (95\% C.I.). In other cases least squares means are presented with associated standard errors.

\section{Results}

\section{Experiment 1}

Determination of location and number of spermatozoa in the cervix

Sperm number was greatest in the region closest to the cervical os and decreased as distance from the os increased in both the channels and lumen $(P<0.001$; Fig. 2). There were more spermatozoa in the cervical channels in the region closest to the cervical os in Belclare than Suffolk ewes, and this was reflected in a breed-by-region interaction ( $P=0.05$; Fig. 2). The number of spermatozoa in the cervical lumen was not affected by breed $(P=0.66)$ and there was no evidence for a breed-by-region interaction $(P=0.51)$. No spermatozoa were found in the UTJs of any ewe and there was no difference between the breeds in cervical length $(P=0.2$; average length of $7.8 \pm 0.20 \mathrm{~cm}$ ).

\section{Cervical mucus sialic acid and fucose quantification}

The proportion of cervical epithelium positively stained for sialic acid was higher in Suffolk than Belclare ewes $(P=0.05$; Fig. 3), indicating greater sialic acid production in Suffolk. The magnitude of the breed difference in sialic acid depended on cervical location, with Suffolk ewes exhibiting twice the amount of staining for sialic acid than Belclare ewes in the cervical channels and this was reflected in a significant breed-by-location interaction $(P=0.03$; Fig. 4). Sialic acid content decreased in the
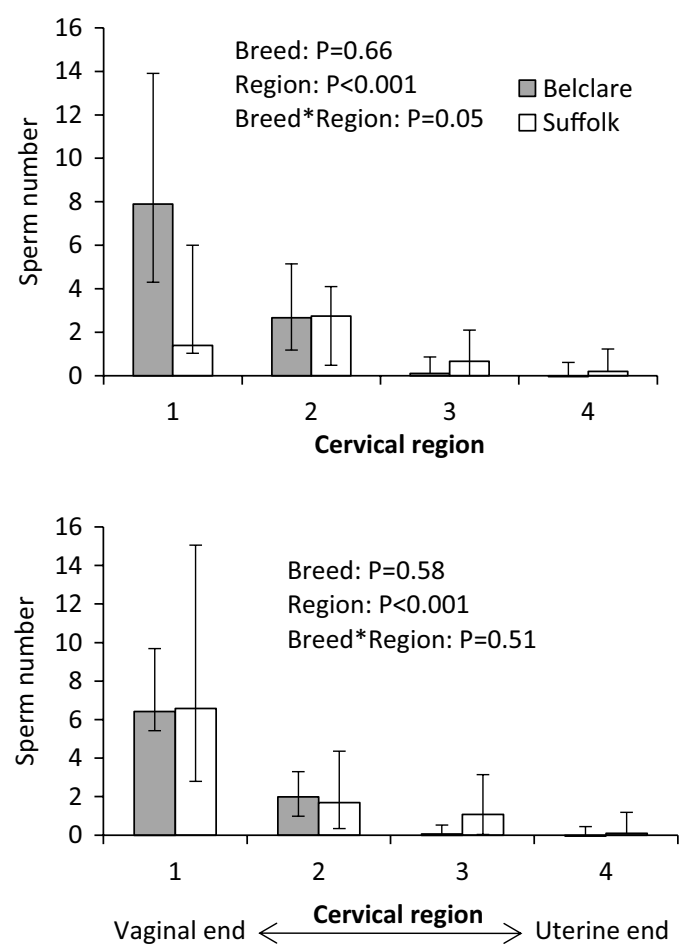
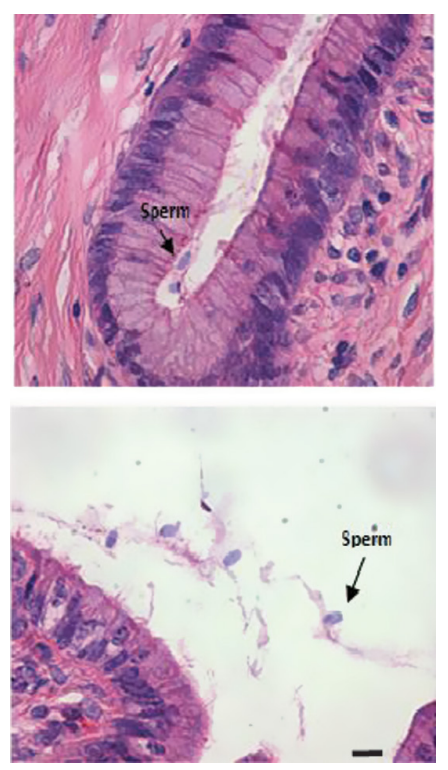

.

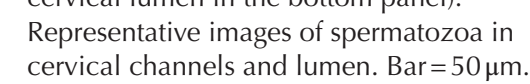

Figure 2 Mean (with 95\% C.I.) number of spermatozoa in a selection of cervical sections of Belclare $(n=18)$ and Suffolk $(n=14)$ ewes after cervical insemination with $200 \times 10^{6}$ frozen-thawed sperm. Ewes were slaughtered $4 \mathrm{~h}$ after cervical insemination with frozenthawed semen and the cervix was dissected into eight regions along the length of the cervix. Four alternate cervical regions from the vaginal end (Region 1) to the uterine end (Region 4) were sectioned and stained with haematoxylin and eosin. The number of spermatozoa in four sections from each region was categorized according to location (cervical channels in the top panel, and cervical lumen in the bottom panel). 

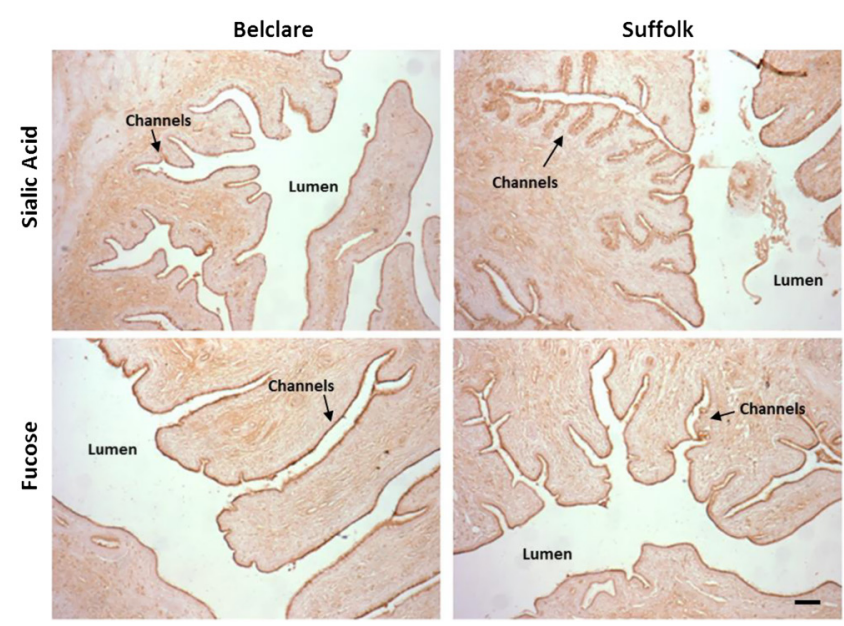

Figure 3 Representative images of sections of cervical tissue from Belclare and Suffolk ewes stained for sialic acid and fucose in the cervical channels and lumen, showing similar levels of fucose for both breeds and higher sialic acid levels in the cervical channels of Suffolk ewes compared with Belclare ewes. Sialic acid and fucose were visualized using the lectins, Sambucus nigra and Ulex europaeus, respectively. Bar $=200 \mu \mathrm{m}$.

region closest to the uterus compared with all other regions (data not shown).

Cervical mucus fucose content was not affected by ewe breed ( $P=0.94$; Fig. 4) or cervical location (lumen compared to channels; $P=0.16$ ) and there was no evidence for any interactions between these factors. However, the amount of fucose in the cervix was affected by cervical region (cervical os toward uterine end of the cervix), reflecting a reduction in fucose content as the sections progressed from the vaginal to the uterine regions (data not shown). This gradation in fucose content along the length of the cervix was not different between breeds.

\section{Experiment 2}

\section{Gene expression}

Glycosyltransferase gene expression The expression of ST6GAL1 was higher in Suffolk ewes than Belclare ewes at $48 \mathrm{~h}$ post pessary removal, reflected in a significant quadratic breed-by-time interaction $(P<0.01$; Table 1$)$. There was no overall effect of breed $(P=0.24)$ or time post pessary removal $(P=0.46)$ on ST6GAL1 expression. FUT1 expression was affected by ewe breed $(P=0.01$; Table 1), with higher expression in Suffolk than Belclare ewes. Expression did not change over time $(P=0.54)$ and there was no breed-by-time interaction $(P=0.41)$.

MUC gene expression There was an effect of breed on MUC5AC expression in the cervix $(P<0.01$; Table 1$)$ with higher expression in Suffolk ewes than Belclare ewes at all time points. There was no significant effect of time post pessary removal $(P=0.57)$ and no breed-bytime interaction $(P=0.17)$.
MUC5B expression was highest at $42 \mathrm{~h}$ post pessary removal and declined linearly to its lowest expression at $57 \mathrm{~h}$ post pessary removal and this was reflected in a significant linear time effect $(P<0.001$; Table 1$)$. Expression level was not affected by ewe breed $(P=0.87)$. However, expression of MUC5B tended to be higher in Suffolk ewes than Belclare ewes at $42 \mathrm{~h}$ post pessary removal, reflected in a quadratic breedby-time interaction that approached formal significance $(P=0.09)$.

MUC6 expression was also affected by time post pessary removal, with expression lowest at $48 \mathrm{~h}$ post pessary removal, reflected in a significant quadratic effect of time $(P<0.01$; Table 1$)$. Expression not affected by ewe breed $(P=0.93)$ or breed-by-time interaction $(P=0.28)$.

Glycosidase activity There was no effect of ewe breed or time post pessary removal and there was no interaction on any of the glycosidases measured $(P>0.05$ in all cases; Supplementary Fig. 1).


Figure 4 Mean (with 95\% C.I.) percentage staining for sialic acid (A) and fucose $(B)$ in the cervical epithelial cells of channels vs the lumen (location). Belclare $(n=18)$ and Suffolk $(n=14)$ ewes were slaughtered $4 \mathrm{~h}$ post cervical insemination with frozen-thawed semen and the cervix was dissected into regions along the length of the cervix. The proportion of sialic acid and fucose in the cervical epithelium was measured, using Sambucus nigra and Ulex europaeus lectins, respectively, in regions 1, 2, 3 and 4 (see 'Materials and methods' section) and these data are combined here. 
Table 1 Expression of genes (mean with 95\% C.I.) coding for glycosidases and MUCs in the mid-cervical region of Belclare ( $n=34$ ) and Suffolk $(n=27)$ ewes at various times in the peri-ovulatory period. Expression values relative to the housekeeping genes, RPLPO and RPL19.

\begin{tabular}{|c|c|c|c|c|c|c|}
\hline \multirow[b]{2}{*}{ Gene/Breed } & \multicolumn{3}{|c|}{ Time post pessary removal $(h)$} & \multicolumn{3}{|c|}{$P$-values } \\
\hline & 42 & 48 & 57 & Breed & Time & Interaction \\
\hline ST6GAL1 & & & & n.s. & n.s. & $<0.01$ \\
\hline Belclare & $1.08(0.17-1.64)$ & 0.67 (0.41-1.09) & $1.21(0.80-1.83)$ & & & \\
\hline Suffolk & $0.81(0.52-1.27)$ & $1.61(1.0-2.62)$ & $1.11(0.70-1.77)$ & & & \\
\hline FUT1 & & & & 0.01 & n.s. & n.s. \\
\hline Belclare & $0.97(0.60-1.59)$ & $1.04(0.63-1.72)$ & $0.94(0.57-1.53)$ & & & \\
\hline Suffolk & $1.06(0.65-1.75)$ & $1.19(0.72-1.97)$ & $1.24(0.75-2.05)$ & & & \\
\hline MUC5AC & & & & $<0.01$ & n.s. & n.s. \\
\hline Belclare & $0.99(0.10-9.66)$ & $0.23(0.02-2.48)$ & $0.51(0.05-5.00)$ & & & \\
\hline Suffolk & $2.03(0.20-20.89)$ & $3.64(0.33-39.93)$ & $1.40(0.13-14.85)$ & & & \\
\hline MUC5B & & & & n.s. & $<0.001$ & n.s. \\
\hline Belclare & $1.18(0.53-2.63)$ & $1.18(0.50-2.83)$ & $0.75(0.34-1.66)$ & & & \\
\hline Suffolk & $1.69(0.73-3.88)$ & $1.20(0.50-2.87)$ & $0.47(0.20-1.10)$ & & & \\
\hline MUC6 & & & & n.s. & $<0.01$ & n.s. \\
\hline Belclare & $1.17(0.92-1.50)$ & $0.69(0.50-0.94)$ & $1.13(0.88-1.44)$ & & & \\
\hline Suffolk & $0.92(0.69-1.21)$ & $0.86(0.63-1.17)$ & $1.12(0.83-1.51)$ & & & \\
\hline
\end{tabular}

n.s., not significant $(P>0.05)$.

Sialic acid speciation The HPLC profile of purified cervical mucin displayed two major peaks at retention times corresponding to 5-N-acetyl- and 5- $\mathrm{N}$-glycolyl sialic acid (Neu5Gc and Neu5Gc, respectively), which are acetylated or glycolylated at the five-carbon position of the molecule. In addition, minor peaks, corresponding to a number of $O$-acetylated forms, were present corresponding to 5 - $\mathrm{N}$-acetyl-7-O-acetylneuraminic acid (Neu5,7Ac2), 5-N-acetyl-9-O-acetylneuraminic acid (Neu5,9Ac2) and 5-N-acetyl-7(8),9-di-Oacetylneuraminic acid (Neu,5,7(8),9Ac3) and 5-N-glycolyl-9-O-acetylneuraminic acid (Neu5, Gc9Ac). Levels of Neu5Ac differed significantly between the breeds $(P<0.05$; Fig. 5$)$, with higher levels in Belclare ewes than Suffolk ewes. Conversely, the quantity of Neu5Gc was higher in Suffolk than Belclare ewes $(P=0.03)$. There was no difference between the breeds in the levels of Neu5,7Ac2, Neu5,9Ac2, Neu,5,7(8),9Ac3 or Neu5,Gc9Ac ( $P>0.4$ in all cases).

\section{Experiment 3}

When cervical mucus was incubated with $6^{\prime}$-sialyllactose, there was an effect of the concentration of $6^{\prime}$-sialyllactose on sperm penetration through cervical mucus ( $P=0.03$; Fig. 6$)$. Sialyllactose positively increased sperm penetration up to a concentration of $30 \mathrm{mM}$. However, sperm penetration at a concentration of $90 \mathrm{mM}$ was similar to that of control. The specificity of sperm binding to the sialic acid component of 6 '-sialyllactose was confirmed, as the addition of $30 \mathrm{mM}$ lactose alone had no effect on sperm penetration through cervical mucus $(P=0.24)$. When spermatozoa were incubated with $6^{\prime}$-sialyllactose prior to the cervical mucus penetration test, there was no effect on sperm penetration through cervical mucus (Fig. 5).

\section{Discussion}

Following the observation that pregnancy rates are lower in Suffolk than Belclare ewes after cervical AI with frozen-thawed semen, we examined sperm transport through the cervix in these ewe breeds. Our main

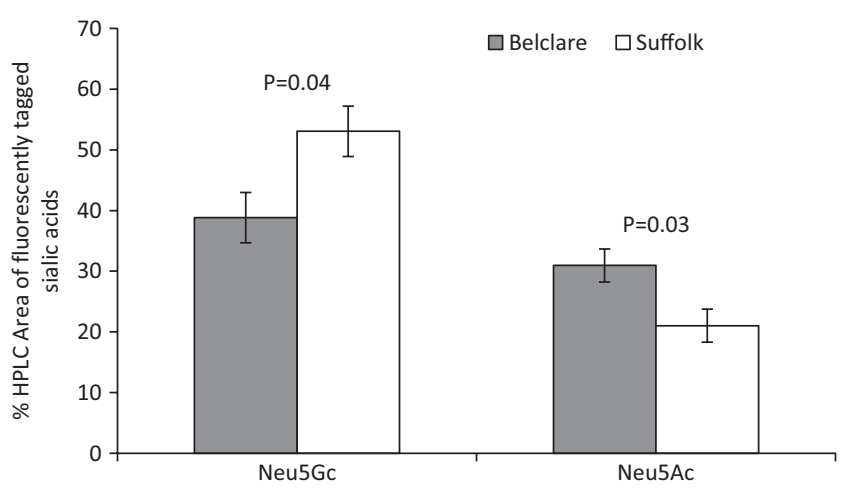

Figure 5 Mean ( \pm S.E.M.) levels of Neu5Gc and Neu5Ac in cervical mucus from Belclare and Suffolk ewes as analysed using high performance liquid chromatography (HPLC). Mucus was collected from Belclare and Suffolk ewes at $42 \mathrm{~h}(n=13)$ or $57 \mathrm{~h}(n=12)$ post pessary removal. Mucus was purified from six ewes (three per breed) and the remainder pooled according to breed and time post pessary removal. As time post pessary removal was not significant, data from both time points were pooled within the ewe breed. 

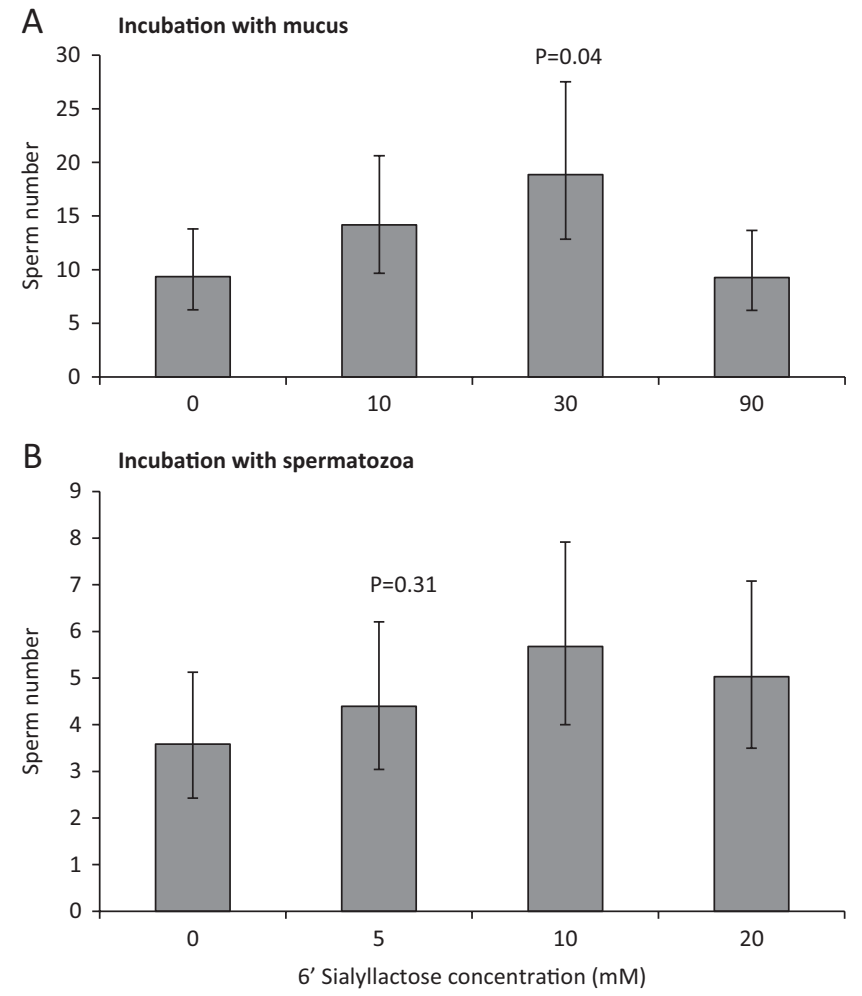

Figure 6 Mean log number of spermatozoa (with 95\% C.I.) penetrating cervical mucus following the addition of sialyllactose to (A) cervical mucus or (B) spermatozoa. Mucus was collected from ewes of various breeds $(n=11)$ at $57 \mathrm{~h}$ post pessary removal and pooled. In experiment (A) mucus was incubated with $6^{\prime}$-sialyllactose at various concentrations for $1 \mathrm{~h}$ at $4^{\circ} \mathrm{C}$ prior to a mucus penetration test. In (B) spermatozoa were incubated for $20 \mathrm{~min}$ with

6 '-sialyllactose at various concentrations prior to a mucus penetration test.

finding was that, within the cervical channels in which spermatozoa travel to the uterus, the likely impairment of sperm transport in Suffolk ewes was caused by higher concentration of sialic acid.

There were a greater number of spermatozoa present in the channels of the cervix in the region closest to the cervical os in Belclare ewes than Suffolk ewes, but this difference was not evident in the cervical lumen. It was surprising that the number of spermatozoa was higher in Belcare ewes in the region closest to the cervix but not in other regions as has been shown in other studies (Lightfoot \& Salmon 1970). The lack of a difference between breeds in the number of spermatozoa in the cervical lumen suggests that in Belclare ewes, more spermatozoa entered the channels and as a result were in a more favourable position to progress through the cervix to reach the uterus. In contrast, in Suffolk ewes, a higher proportion of spermatozoa remained in the lumen and failed to enter the channels exposing them to a greater risk of loss through retrograde flow. The movement of spermatozoa into the cervical channels following entry into the cervix is illustrated by data from studies, in sheep (Mattner \& Braden 1969) and humans (Insler et al. 1980), where the distribution of spermatozoa in the cervix following insemination of abnormal or dead spermatozoa vs live spermatozoa was compared. Normal spermatozoa were found to colonize cervical channels, while abnormal or dead spermatozoa remained in the cervical lumen (Rutllant et al. 2005). This comparison reveals that normal spermatozoa migrate to the cervical channels following entry into the cervix, thus indicating that this is the preferential route for sperm transit through the cervix.

The modulation of mucin glycans and mucus receptivity to spermatozoa throughout reproductive cycles suggests that the ability of spermatozoa to migrate through the cervix is largely a result of the dynamic biochemical changes in cervical mucus composition (Andersch-Bjorkman et al. 2007). We have provided evidence that the reason more spermatozoa were in the cervical channels of Belclare ewes than Suffolk ewes was due to the terminal glycosylation pattern of cervical mucins in the channels and lumen of these breeds. The expression of sialic acid in the cervical channels of Suffolk ewes was approximately twice that of Belclare ewes. This suggests that sialic acid serves as a modulator for sperm transport through the cervix (McGetrick et al. 2014) and may be the cause of low numbers of spermatozoa in the cervical channels of Suffolk ewes. Reports on the role of sialic acid in the regulation of sperm transport during the periovulatory phase have been contradictory. Lutjen et al. (1985) reported a decrease in terminal sialic acid in cervical mucus from infertile human patients with a cervical factor of non-immunological origin than in normal cervical mucus collected at the same phase of the menstrual cycle. In contrast, others have reported the opposite relationship between sialic acid content and sperm penetrability, with a decrease in sialic acid content coincident with an increase in mucus receptivity to spermatozoa (Moghissi \& Syner 1976). The present study, however, examined sialic acid content in specific locations within the cervical canal (i.e. channels vs lumen) in relation to fertility and provides evidence that the compromised ability of spermatozoa to travel through the cervical channels in Suffolk ewes is due to increased sialic acid content.

Cervical mucus undergoes constant turnover and degradation, especially at oestrus when mucus production is at its highest (Maddison et al. 2016, 2017). During mucin synthesis, sialic acid and fucose are transferred to underlying residues in the Golgi apparatus via a series of transferases (Du et al. 2009). Expression of a sialyltransferase, ST6GAL1, and a fucosyltransferase, FUT1, were different between ewe breeds. Higher expression of ST6GAL1 was observed in Suffolk than Belclare ewes at $48 \mathrm{~h}$ post pessary removal. Complete mucin synthesis has been reported to take at least $6 \mathrm{~h}$ (Rose \& Voynow 2006); therefore the high expression of ST6GAL1 in Suffolk ewes at $48 \mathrm{~h}$ post pessary 
removal may be responsible for the higher abundance of sialic acid in the cervical channels around the time of ovulation. Suffolk ewes had higher FUT1 expression than Belclare ewes at all times post pessary removal; however, the difference between the breeds in FUT1 expression was not as great as that between the breeds in ST6GAL1 expression. This suggests that an anomaly in sialic acid content may be the primary cause of differences between the ewe breeds in sperm transit through the cervix. Mucin degradation occurs through the actions of glycosidases, where the first step is the cleavage of terminal sugars (Pluta et al. 2011). In this study, neither sialidase nor fucosidase activity differed between the breeds at any time point post pessary removal. This suggests that the higher expression of ST6GAL1 in the cervix of Suffolk ewes was not reflected in higher levels of sialidase activity, therefore pointing to an imbalance of sialic acid production and degradation in this breed.

The increased expression in Suffolk ewes of both sialic acid and the ST6GAL1 gene in the cervical channels provides evidence for the involvement of $\alpha 2,6$ linked sialic acid in the inhibition of sperm transit through the cervical channels in Suffolk ewes. However, sialic acid residues can be present not just in various linkages but also in various structures. The sialic acids are a family of sugars with a shared nine-carbon backbone structure. There are over 50 structural variations in nature, the most prevalent being $\mathrm{N}$-acetylneuraminic acid (Neu5Ac) and N-glycoylneuraminic acid (Neu5Gc; Varki 2007). Sambucus nigra lectin binds to both variants of sialic acid, while ST6GAL1 encodes for the transfer of both variants to an underlying galactose (Brinkman-Van der Linden et al. 2002). Therefore, the presence of both Neu5Ac and Neu5Gc forms of sialic acids in ewe cervical mucus was investigated using HPLC. Interestingly, Neu5Gc was higher in Suffolk than Belclare ewes, while Neu5Ac was higher in Belclare ewes than Suffolk ewes. Neu5Ac is the precursor for all sialic acid species (Du et al. 2009) and it is catalysed to Neu5Gc via the enzyme cytidine monophosphate- $\mathrm{N}$-acetylneuraminic acid hydroxylase (CMAH). The conversion of Neu5Ac to Neu5Gc in Suffolk ewes appears to exceed that in Belclare ewes and the higher presence of Neu5Gc in Suffolk ewes may have important implications for sperm transport through the cervical channels. The conversion of Neu5Ac to Neu5Gc does not occur in humans as a genetic mutation, occurring approximately 2 million years ago, resulted in the loss of the activity of $\mathrm{CMAH}$ (Gagneux \& Varki 2001); therefore, any detrimental effect of Neu5Gc on sperm migration would not be evident in humans.

The identities of the mucins to which specific glycans are attached are unknown. Thus, it is not known whether the higher quantity of sialic acid in the cervix of Suffolk ewes reflects altered levels of specific mucins at oestrus or just an alteration in the glycosylation pathway. However, the expression of the most abundant gel-forming mucins in the cervix has been found to vary throughout the menstrual cycle in women. Concentrations of MUC5AC, MUC5B and MUC6 proteins have been reported to peak in human ovulatory cervical mucus, with MUC5B being the most abundant in terms of protein and mRNA expression and is the main gel-forming mucin responsible for the viscoelastic properties of cervical mucus (Gipson 2001, AnderschBjorkman et al. 2007). MUC5B has been shown to be more abundant in cervical mucus collected during the follicular phase, when progesterone is at its lowest, than the luteal phase in both sheep (Soleilhavoup et al. 2016) and humans (Gipson 2001) when progesterone is at its lowest. In this study using quantitative real-time PCR, MUC5AC had consistently higher expression across all time points post pessary removal than $M U C 5 B$ and MUC6 suggesting that, in the ewe, MUC5AC dominates at the time of oestrus. The role of MUC5AC in sperm penetration through the cervix remains unclear. It may play a role in mucus rheology as MUC5AC mucins are very long linear flexible threads, which may be in excess of $10 \mu \mathrm{m}$ in length (Sheehan et al. 2000), and mucus rheology is governed by the degree of entanglement and crosslinking of cervical mucins (Portal et al. 2017). Indeed, in a previous study by our group the rheological properties of cervical mucus were found to differ between Belclare and Suffolk ewes, with cervical mucus from Suffolk ewes tending to be more elastic than that from Belclare ewes (Richardson et al. 2011).

Results of this study provide evidence for an effect of ewe breed on sialic acid expression in the cervix. Glycan interactions between the female reproductive tract and spermatozoa (Tecle \& Gagneux 2015) have been reported to occur in both the oviductal epithelium (Apichela et al. 2010, Kadirvel et al. 2012, Narciandi et al. 2016, Lyons et al. 2018) and zona pellucida (Lassalle \& Testart 1994, Velasquez et al. 2007, Pang et al. 2011) of various species. Yu et al. (2018) proposed that phagocytosis in the female reproductive tract is mediated through L-selectin on leukocytes which binds sialic acid on the sperm surface, thus providing further evidence that the sperm sialome is correlated with spermatozoa survival within the female genital tract (Ma et al. 2016). Recently our group demonstrated that while the removal of sialic acid from bull spermatozoa decreased motility and mucus penetration ability, its removal increased zona pellucida binding and polyspermic penetration in vitro (Fernandez-Fuertes et al. 2018), thus providing further evidence of a key role in sperm transport prior to capacitation.

The role of sialic acid in impairing sperm transit through the cervix of Suffolk ewes may be mediated through the binding of spermatozoa to cervical mucins via a sialic-acid-recognizing protein on the sperm surface (Ma et al. 2016, Alkhodair et al. 2018, Fernandez-Fuertes 
et al. 2018), thus causing them to become attached to the large mucin glycoproteins. To block the sialic-acidrecognizing receptor on the sperm head from binding to cervical mucins we added free sialic acid, in the form of the trisaccharide 6 '-sialyllactose, to either cervical mucus or ram spermatozoa and performed a mucus penetration test. Consistent with the hypothesis, this led to an increase in the ability of spermatozoa to penetrate cervical mucus demonstrating that spermatozoa were able to avoid attachment to the cervical mucin molecules and progress through the cervical mucus. This is in agreement with the work by Tollner et al. (2011), who demonstrated that spermatozoa from men with mutations in DEFB126 have lower lectin binding, which is associated with fewer O-linked oligosaccharides, an altered ability to penetrate synthetic mucus and reduced fertility. Indeed, beta-defensins are conserved across mammalian species and are expressed within both male and female reproductive tissues as demonstrated by our group for equine (Johnson et al. 2016), bovine (Narciandi et al. 2011, 2014) and ovine (Hall et al. 2017) subjects. The addition of sialic acid moieties to defensin peptides confers a negative charge to spermatozoa, thereby repelling the negatively charged mucus and facilitating migration of non-capacitated spermatozoa through electronegative mucus (Tecle \& Gagneux 2015). In the current study, a peak in sperm penetration was observed when cervical mucus was incubated with $30 \mathrm{mM} 6^{\prime}$-sialyllactose. Although the effect of adding 6 '-sialyllactose to sperm prior to a cervical mucus penetration test was not significant, there was a trend for an increase in sperm penetration. Recognition and binding between spermatozoa and cervical mucins may be as a result of multimeric binding (Lassalle \& Testart 1996). Sialyllactose is a monomeric binding molecule; therefore, a higher concentration may be required in order to observe a significant effect on sperm penetration through mucus.

In conclusion, the glycosylation pattern of cervical mucins in different locations within the cervix appears to be related to the ability of the cervical channels to support sperm migration. The higher sialic acid content in the cervical channels of Suffolk ewes than Belclare ewes indicates that frozen-thawed sperm migration is restricted by high levels of this residue. Sialic acid may function to mediate the binding of spermatozoa to cervical mucins via a sialic-acid-recognizing protein on spermatozoa, causing spermatozoa to become immobilized, and this binding interaction may be competitively inhibited by adding sialic acid to cervical mucus to block sialic-acid-recognizing receptors on the sperm surface. Dysfunction in mucus sialylation in women with impaired fertility has yet to be demonstrated; however, the results of this study, using a novel animal model, have identified the importance of sialic acid in the migration of spermatozoa through the cervix.

\section{Supplementary data}

This is linked to the online version of the paper at https://doi.org/10.1530/REP-18-0547.

\section{Declaration of interest}

The authors declare that there is no conflict of interest that could be perceived as prejudicing the impartiality of the research reported.

\section{Funding}

This work was funded by contributions from Teagasc under the Walsh Fellowships Scheme, Science Foundation Ireland, as part of the Reproductive Biology Research Cluster (07/SRC/B1156) as well as the European Research Area Network on Sustainable Animal Production (Grant no. 16/RD/SusAn/ERA-NET).

\section{Author contribution statement}

S Fair, L Richardson, J P Hanrahan, P Lonergan and A C O Evans conceived the study and designed the experiments. S D Carrington assisted with the mucus and tissue characterization, while T Tharmalingham performed the sialic acid speciation. $\mathrm{L}$ Richardson performed the experiments and drafted the manuscript with the assistance of S Fair and A C O Evans. All authors proofread the manuscript.

\section{Acknowledgements}

The assistance of Tom Lally, Daragh Matthews and Pat Duffy for the care and feeding of the animals is gratefully acknowledged. The authors thank Eamonn Fitzpatrick for his assistance on the histology, Katarzyna Pluta, Mary Gallagher and Jane Irwin on the mucin extraction and analysis as well as John Browne for his help with the PCR.

\section{References}

Alkhodair K, Almhanna H, McGetrick J, Gedair S, Gallagher ME, Fernandez-Fuertes B, Tharmalingam T, Larsen PB, Fitzpatrick E, Lonergan P, et al. 2018 Siglec expression on the surface of human, bull and ram sperm. Reproduction 155 361-371. (https://doi.org/10.1530/ REP-17-0475)

Andersch-Bjorkman Y, Thomsson KA, Larssont JMH, Ekerhovd E \& Hansson GC 2007 Large scale identification of proteins, mucins, and their O-glycosylation in the endocervical mucus during the menstrual cycle. Molecular and Cellular Proteomics 6 708-716. (https://doi. org/10.1074/mcp.M600439-MCP200)

Apichela SA, Valz-Gianinet JN, Schuster S, Jimenez-Diaz MA, RoldanOlarte EM \& Miceli DC 2010 Lectin binding patterns and carbohydrate mediation of sperm binding to Ilama oviductal cells in vitro. Animal Reproduction Science $\mathbf{1 1 8}$ 344-353. (https://doi.org/10.1016/j. anireprosci.2009.07.008)

Bansil R \& Turner BS 2006 Mucin structure, aggregation, physiological functions and biomedical applications. Current Opinion in Colloid and Interface Science 11 164-170. (https://doi.org/10.1016/j. cocis.2005.11.001)

Brinkman-Van der Linden EC, Sonnenburg JL \& Varki A 2002 Effects of sialic acid substitutions on recognition by Sambucus nigra agglutinin 
and Maackia amurensis hemagglutinin. Analytical Biochemistry 303 98-104. (https://doi.org/10.1006/abio.2001.5539)

Cone RA 2009 Barrier properties of mucus. Advanced Drug Delivery Reviews 61 75-85. (https://doi.org/10.1016/j.addr.2008.09.008)

Corfield AP \& Myerscough N 2000 Glycosidase activity. Methods in Molecular Biology 125 403-416. (https://doi.org/10.1385/1-59259-0489:403)

Curlin M \& Bursac D 2013 Cervical mucus: from biochemical structure to clinical implications. Frontiers in Bioscience 5 507-515. (https://doi. org/10.2741/S386)

Donovan A, Hanrahan JP, Duffy P \& Boland MP 2000 Al in sheep: breed differences in timing of ovulation. Irish Journal of Agricultural and Food Research 393.

Donovan A, Hanrahan JP, Kummen E, Duffy P \& Boland MP 2004 Fertility in the ewe following cervical insemination with fresh or frozen-thawed semen at a natural or synchronised oestrus. Animal Reproduction Science 84 359-368. (https://doi.org/10.1016/j.anireprosci.2003.12.014)

Du J, Meledeo MA, Wang Z, Khanna HS, Paruchuri VD \& Yarema KJ 2009 Metabolic glycoengineering: sialic acid and beyond. Glycobiology 19 1382-1401. (https://doi.org/10.1093/glycob/cwp115)

Ellingham RB, Berry M, Stevenson D \& Corfield AP 1999 Secreted human conjunctival mucus contains MUC5AC glycoforms. Glycobiology $\mathbf{9}$ 1181-1189. (https://doi.org/10.1093/glycob/9.11.1181)

Fair S, Hanrahan JP, O'Meara CM, Duffy P, Rizos D, Wade M, Donovan A, Boland MP, Lonergan P \& Evans AC 2005 Differences between Belclare and Suffolk ewes in fertilization rate, embryo quality and accessory sperm number after cervical or laparoscopic artificial insemination. Theriogenology 63 1995-2005. (https://doi.org/10.1016/j. theriogenology.2004.09.005)

Fernandez-Fuertes B, Blanco-Fernandez A, Reid CJ, Meade KG, Fair S \& Lonergan P 2018 Removal of sialic acid from bull sperm decreases motility and mucus penetration ability but increases zona pellucida binding and polyspermic penetration in vitro. Reproduction 155 481-492. (https://doi.org/10.1530/REP-17-0429)

Fernandez-Hermida Y, Grande G, Menarguez M, Astorri AL \& Azagra R 2018 Proteomic markers in cervical mucus. Protein and Peptide Letters 25 463-471. (https://doi.org/10.2174/0929866525666180418122705)

Gagneux P \& Varki A 2001 Genetic differences between humans and great apes. Molecular Phylogenetics and Evolution 18 2-13. (https://doi. org/10.1006/mpev.2000.0799)

Gipson IK 2001 Mucins of the human endocervix. Frontiers in Bioscience 6 D1245-D1255. (https://doi.org/10.2741/A677)

Hall TJ, McQuillan C, Finlay EK, O'Farrelly C, Fair S \& Meade KG 2017 Comparative genomic identification and validation of beta-defensin genes in the Ovis aries genome. BMC Genomics 18 278. (https://doi. org/10.1186/s12864-017-3666-X)

Insler V, Glezerman M, Zeidel L, Bernstein D \& Misgav N 1980 Sperm storage in the human cervix: a quantitative study. Fertility and Sterility 33 288-293. (https://doi.org/10.1016/S0015-0282(16)44596-6)

Irwin JA, Morrissey PE, Ryan JP, Walshe A, $\mathrm{O}^{\prime}$ Neill SM, Carrington SD, Matthews E, Fitzpatrick E, Mulcahy G, Corfield AP, et al. 2004 Glycosidase activity in the excretory-secretory products of the liver fluke, Fasciola hepatica. Parasitology 129 465-472. (https://doi.org/10.1017/ S0031182004005803)

Johnson GP, Lloyd AT, O'Farrelly C, Meade KG \& Fair S 2016 Comparative genomic identification and expression profiling of a novel $\beta$-defensin gene cluster in the equine reproductive tract. Reproduction, Fertility and Development 28 1499-1508. (https://doi.org/10.1071/RD14345)

Kaabi M, Alvarez M, Anel E, Chamorro CA, Boixo JC, de Paz P \& Anel L 2006 Influence of breed and age on morphometry and depth of inseminating catheter penetration in the ewe cervix: a postmortem study. Theriogenology 66 1876-1883. (https://doi.org/10.1016/j. theriogenology.2006.04.039)

Kadirvel G, Machado SA, Korneli C, Collins E, Miller P, Bess KN, Aoki K, Tiemeyer M, Bovin N \& Miller DJ 2012 Porcine sperm bind to specific 6-sialylated biantennary glycans to form the oviduct reservoir. Biology of Reproduction 87 147. (https://doi.org/10.1095/biolreprod.112.103879)

Katz DF, Slade DA \& Nakajima ST 1997 Analysis of pre-ovulatory changes in cervical mucus hydration and sperm penetrability. Advances in Contraception 13 143-151. (https://doi.org/10.1023/A:1006543719401)

Kessel RG 1979 A text-atlas of scanning electron microscopy (Freeman, San Francisco). Tissues and Organs 17 1038-1040.
Kiernan JA 2008 Histological and Histochemical Methods. Theory and Practice, 4th ed. Scion Publishing Ltd, Banbury, UK.

Kolle S 2015 Transport, distribution and elimination of mammalian sperm following natural mating and insemination. Reproduction in Domestic Animals = Zuchthygiene 50 (Supplement 3) 2-6. (https://doi.org/10.1111/ rda.12576)

Kremp A \& Anderson DM 2004 Lectin binding patterns of Scrippsiella lachrymosa (Dinophyceae) in relation to cyst formation and nutrient conditions. Journal of Experimental Marine Biology and Ecology 307 165-181. (https://doi.org/10.1016/j.jembe.2004.02.004)

Lassalle B \& Testart J 1994 Human zona pellucida recognition associated with removal of sialic acid from human sperm surface. Journal of Reproduction and Fertility 101 703-711. (https://doi.org/10.1530/ jrf.0.1010703)

Lassalle B \& Testart J 1996 Lectins binding on human sperm surface increase membrane permeability and stimulate acrosomal exocytosis. Molecular Human Reproduction 2 651-658. (https://doi.org/10.1093/ molehr/2.9.651)

Lightfoot RJ \& Salmon S 1970 Fertility of ram spermatozoa frozen by the pellet method. I. Transport and viability of spermatozoa within the genital tract of the ewe. Journal of Reproduction and Fertility 22 385-398. (https://doi.org/10.1530/jrf.0.0220385)

Lutjen PJ, Handley CJ, de Witt MT, Trounson AO \& McBain JC 1985 Biochemical changes in cervical mucus-factor infertility. Gamete Research 12 265-274. (https://doi.org/10.1002/mrd.1120120305)

Lyons A, Narciandi F, Donnellan E, Romero-Aguirregomezcorta J, Farrelly CO, Lonergan P, Meade KG \& Fair S 2018 Recombinant -defensin 126 promotes bull sperm binding to bovine oviductal epithelia. Reproduction, Fertility, and Development 30 1472-1481. (https://doi. org/10.1071/RD17415)

Ma X, Pan Q, Feng Y, Choudhury BP, Ma Q, Gagneux P \& Ma F 2016 Sialylation facilitates the maturation of mammalian sperm and affects its survival in female uterus. Biology of Reproduction 94 123. (https://doi. org/10.1095/biolreprod.115.137810)

Maddison JW, Rickard JP, Bernecic NC, Tsikis G, Soleilhavoup C, Labas V, Combes-Soia L, Harichaux G, Druart X, Leahy T, et al. 2017 Oestrus synchronisation and superovulation alter the cervicovaginal mucus proteome of the ewe. Journal of Proteomics 155 1-10. (https://doi. org/10.1016/j.jprot.2017.01.007)

Maddison JW, Rickard JP, Mooney E, Bernecic NC, Soleilhavoup C, Tsikis G, Druart X, Leahy T \& de Graaf SP 2016 Oestrus synchronisation and superovulation alter the production and biochemical constituents of ovine cervicovaginal mucus. Animal Reproduction Science $\mathbf{1 7 2}$ 114-122. (https://doi.org/10.1016/j.anireprosci.2016.07.008)

Martyn F, McAuliffe FM \& Wingfield M 2014 The role of the cervix in fertility: is it time for a reappraisal? Human Reproduction 29 2092-2098. (https://doi.org/10.1093/humrep/deu195)

Mattner PE \& Braden AWH 1969 Comparison of distribution of motile and immotile spermatozoa in ovine cervix. Australian Journal of Biological Sciences 22 1069-1070. (https://doi.org/10.1071/BI9691069)

McGetrick JA, Reid CJ \& Carrington SD 2014 Improving bovine semen diluents: insights from the male and female reproductive tracts, and the potential relevance of cervical mucins. Animal 8 (Supplement 1) 173-184. (https://doi.org/10.1017/S1751731114000287)

Menarguez M, Pastor LM \& Odeblad E 2003 Morphological characterization of different human cervical mucus types using light and scanning electron microscopy. Human Reproduction 18 1782-1789. (https://doi.org/10.1093/humrep/deg382)

Miki K \& Clapham DE 2013 Rheotaxis guides mammalian sperm. Current Biology 23 443-452. (https://doi.org/10.1016/j.cub.2013.02.007)

Moghissi KS \& Syner FN 1976 Cyclic changes in the amount and sialic acid of cervical mucus. International Journal of Fertility 21 246-250.

Morales P, Roco M \& Vigil P 1993 Human cervical-mucus - relationship between biochemical characteristics and ability to allow migration of spermatozoa. Human Reproduction 8 78-83. (https://doi.org/10.1093/ oxfordjournals.humrep.a137879)

Mullins KJ \& Saacke RG 1989 Study of the functional anatomy of bovine cervical mucosa with special reference to mucus secretion and sperm transport. Anatomical Record 225 106-117. (https://doi.org/10.1002/ ar.1092250205)

Narciandi F, Fernandez-Fuertes B, Khairulzaman I, Jahns H, King D, Finlay EK, Mok KH, Fair S, Lonergan P, Farrelly CO, et al. 2016 Sperm- 
coating beta-defensin 126 is a dissociation-resistant dimer produced by epididymal epithelium in the bovine reproductive tract. Biology of Reproduction 95 121. (https://doi.org/10.1095/biolreprod.116.138719)

Narciandi F, Lloyd A, Meade KG \& O'Farrelly C 2014 A novel subclass of bovine beta-defensins links reproduction and immunology. Reproduction, Fertility and Development 26 769-777. (https://doi. org/10.1071/RD13153)

Narciandi F, Lloyd AT, Chapwanya A, O'Farrelly C \& Meade KG 2011 Reproductive tissue-specific expression profiling and genetic variation across a 19 gene bovine beta-defensin cluster. Immunogenetics 63 641-651. (https://doi.org/10.1007/s00251-011-0551-7)

Pang PC, Chiu PC, Lee CL, Chang LY, Panico M, Morris HR, Haslam SM, Khoo KH, Clark GF, Yeung WS, et al. 2011 Human sperm binding is mediated by the sialyl-Lewis(x) Oligosaccharide on the zona pellucida. Science 333 1761-1764. (https://doi.org/10.1126/science.1207438)

Paulenz H, Adnoy T \& Soderquist L 2007 Comparison of fertility results after vaginal insemination using different thawing procedures and packages for frozen ram semen. Acta Veterinaria Scandinavica 4926 (https://doi.org/10.1186/1751-0147-49-26)

Paulenz H, Soderquist L, Adnoy T, Nordstoga AB \& Andersen Berg K 2005 Effect of vaginal and cervical deposition of semen on the fertility of sheep inseminated with frozen-thawed semen. Veterinary Record $\mathbf{1 5 6}$ 372-375. (https://doi.org/10.1136/vr.156.12.372)

Pluta K, Irwin JA, Dolphin C, Richardson L, Fitzpatrick E, Gallagher ME, Reid CJ, Crowe MA, Roche JF, Lonergan P, et al. 2011 Glycoproteins and glycosidases of the cervix during the periestrous period in cattle. Journal of Animal Science 89 4032-4042. (https://doi.org/10.2527/ jas.2011-4187)

Pluta K, McGettigan PA, Reid CJ, Browne JA, Irwin JA, Tharmalingam T, Corfield A, Baird A, Loftus BJ, Evans ACO, et al. 2012 Molecular aspects of mucin biosynthesis and mucus formation in the bovine cervix during the periestrous period. Physiological Genomics 44 1165-1178. (https:// doi.org/10.1152/physiolgenomics.00088.2012)

Portal C, Gouyer V, Magnien M, Plet S, Gottrand F \& Desseyn JL 2017 In vivo imaging of the Muc5b gel-forming mucin. Scientific Reports 7 44591. (https://doi.org/10.1038/srep44591)

Richardson L, Hanrahan JP, O'Hara L, Donovan A, Fair S, O'Sullivan M Carrington SD, Lonergan P \& Evans AC 2011 Ewe breed differences in fertility after cervical Al with frozen-thawed semen and associated differences in sperm penetration and physicochemical properties of cervical mucus. Animal Reproduction Science 129 37-43. (https://doi org/10.1016/j.anireprosci.2011.10.012)

Rose MC \& Voynow JA 2006 Respiratory tract mucin genes and mucin glycoproteins in health and disease. Physiological Reviews 86 245-278. (https://doi.org/10.1152/physrev.00010.2005)

Royle L, Matthews E, Corfield A, Berry M, Rudd PM, Dwek RA \& Carrington SD 2008 Glycan structures of ocular surface mucins in man, rabbit and dog display species differences. Glycoconjugate Journal 25 763-773. (https://doi.org/10.1007/s10719-008-9136-6)

Rutllant J, Lopez-Bejar M \& Lopez-Gatius F 2005 Ultrastructural and rheological properties of bovine vaginal fluid and its relation to sperm motility and fertilization: a review. Reproduction in Domestic Animals 40 79-86. (https://doi.org/10.1111/j.1439-0531.2004.00510.x)

Sakkas D, Ramalingam M, Garrido N \& Barratt CL 2015 Sperm selection in natural conception: what can we learn from Mother Nature to improve assisted reproduction outcomes? Human Reproduction Update $\mathbf{2 1}$ 711-726. (https://doi.org/10.1093/humupd/dmv042)

Sheehan JK, Brazeau C, Kutay S, Pigeon H, Kirkham S, Howard M \& Thornton DJ 2000 Physical characterization of the MUC5AC mucin: a highly oligomeric glycoprotein whether isolated from cell culture or in vivo from respiratory mucous secretions. Biochemical Journal $347(\mathrm{Pt} 1)$ 37-44. (https://doi.org/10.1042/bj3470037)

Soleilhavoup C, Riou C, Tsikis G, Labas V, Harichaux G, Kohnke P, Reynaud K, de Graaf SP, Gerard N \& Druart X 2016 Proteomes of the female genital tract during the oestrous cycle. Molecular and Cellular Proteomics 15 93-108. (https://doi.org/10.1074/mcp.M115.052332)

Tecle E \& Gagneux P 2015 Sugar-coated sperm: unraveling the functions of the mammalian sperm glycocalyx. Molecular Reproduction and Development 82 635-650. (https://doi.org/10.1002/mrd.22500)

Thornton DJ, Holmes DF, Sheehan JK \& Carlstedt I 1989 Quantitation of mucus glycoproteins blotted onto nitrocellulose membranes. Analytical Biochemistry 182 160-164. (https://doi.org/10.1016/00032697(89)90735-5)

Tollner TL, Venners SA, Hollox EJ, Yudin Al, Liu X, Tang G, Xing H, Kays RJ, Lau T, Overstreet JW, et al. 2011 A common mutation in the defensin DEFB126 causes impaired sperm function and subfertility. Science Translational Medicine 3 92ra65. (https://doi.org/10.1126/ scitranslmed.3002289)

Tung CK, Lin C, Harvey B, Fiore AG, Ardon F, Wu M \& Suarez SS 2017 Fluid viscoelasticity promotes collective swimming of sperm. Scientific Reports 7 3152. (https://doi.org/10.1038/s41598-017-03341-4)

Varki A 2007 Glycan-based interactions involving vertebrate sialic-acidrecognizing proteins. Nature 446 1023-1029. (https://doi.org/10.1038/ nature05816)

Velasquez JG, Canovas S, Barajas P, Marcos J, Jimenez-Movilla M, Gallego RG, Ballesta J, Aviles M \& Coy P 2007 Role of sialic acid in bovine sperm-zona pellucida binding. Molecular Reproduction and Development 74 617-628. (https://doi.org/10.1002/mrd.20619)

Yu L, Zheng Y, Feng Y \& Ma F 2018 Role of L-selectin on leukocytes in the binding of sialic acids on sperm surface during the phagocytosis of sperm in female reproductive tract. Medical Hypotheses 120 4-6. (https://doi.org/10.1016/j.mehy.2018.08.008)

Received 22 October 2018

First decision 30 November 2018

Revised manuscript received 21 December 2018

Accepted 3 January 2019 